\title{
PENGARUH METODE BELAJAR “AKU CEPAT MEMBACA" TERHADAP KEMAMPUAN MEMBACA PERMULAAN PADA ANAK USIA DINI DI TK AISYIYAH 46 SURABAYA
}

\author{
Annisa Octavia Wulasari ${ }^{1}$ \\ TK AiSyiyah 46 Surabaya \\ Email: annisaoctavia602@gmail.com ${ }^{1}$
}

\begin{abstract}
ABSTRAK
Metode belajar aku cepat membaca adalah dapat memberikan pembelajaran yang alternatif dengan konsep bermain sambil belajar dan belajar dengan menyenangkan. Bila mana pada di TK Aisyiyah 46 Surabaya dapat menemukan permasalahan yang dialami anak didik. Dimana dalam permasalahan itu anak belum mampu membaca huruf dengan cepat. Akan tetapi dengan menggunakan metode belajar Aku Cepat Membaca dapat memiliki tujuan dalam penilitian agar anak didik dapat memahami dan bisa membaca secara cepat dan lancar. Yang digunakan melalui metode penelitian kuantitatif untuk membuktikan dengan menggunakan pretest, treatment dan posttest yang memiliki jumlah pretest 192 dengan rata-rata 8,34 sedangkan posttest sejumlah 426 dengan rata-rata 18,5 dalam metode ini dapat mengembangkan kemampuan membaca permulaan anak. Dapat dirumuskan pada hasil penelitian statistik uji Wilcoxon yang merupakan dengan taraf signifikasi $5 \%$ dan $\mathrm{N}=23$, Thitung=0, sehingga Ha diterima $0<73$.
\end{abstract}

Kata kunci: Metode Belajar dan Kemampuan Membaca Permulaan

\begin{abstract}
Learning Method "Aku Cepat Membaca" can become alternative learning with concept of Playing while learning and Fun Learning. Aisyiyah Kindergarten 46 Surabaya has found a problem which has been overcome by their students that they cannot read letters quickly. However, the learning method "Aku Cepat Membaca" applied in this study aimed to resolve the students' problem in understanding letters and reading it quickly and fluently. To prove the learning method effectiveness, this study used quantitative method taken by pretest, treatment and posttest. The total pretests were 192 with mean 8,34 while total posttests were 426 with mean 18,5 which explained that this learning method was able to improve the children's beginner reading ability. It proved by using statistical test with Wilcoxon test which was confirmed by significance level $5 \%$ and $\mathrm{N}=23$, $\mathrm{t}_{\mathrm{value}}=0$, so that Ha was accepted $0<73$.
\end{abstract}

Keywords: Learning method and Beginner Reading Ability

\section{PENDAHULUAN}

Kegiatan

mengembangkan

merupakan serangkaian aktivitas yang disediakan untuk memfasilitasi perkembangan belajar anak di Taman

Kanak-kanak (TK), yang secara umum kegiatan dapat dilakukan di antaranya menyediakan lingkungan 
kondusif yang untuk mengarahkan perilaku anak dengan kegiatan mendidik, mengajar, serta membantu memecahkan berbagai permasalahan yang dihadapi anak dengan bimbingan yang tepat ( Nugraha, 2005: 5-6 (Susanto,2017: 19)). Menurut Sulton \& Tsuroyah, 1998 Mengajarkan membaca untuk anak usia dini, dilakukan dengan menggunakan pendekatan bermain atau media permainan khusus yang sesuai dengan anak-anak. Perlu diketahui bahwa pendidikan anak usia dini masih dalam masa bermain. Anak dirangsang dengan permainan yang menyenangkan dengan melalui proses sebagai berikut : mengamati, memilih, memisah, menggabung/memadu. Dengan cara ini dapat meningkatkan kecerdasan anak. Namun jika diajarkan seperti anak sekolah maka dikhawatirkan dikemudian hari anak menjadi turun tingkat kecerdasannya dan menimbulkan kejenuhan.

Dalam kurikulum disesuaikan dengan kondisi psikologis anak sehingga anak merasa mampu, senang, rileks, dan nyaman belajar. Anak usia dini suka bermain, aktif, dan selalu ingin tahu. Oleh karena itu, kegiatan kurikuler dirancang agar anak dapat belajar sambil bermain, aktif baik secara fisik maupun scara mental untuk memuaskan rasa ingin tahunya.

Salah satu cara mengembangkan kemampuan membaca permulaan adalah dengan menggunakan Metode Belajar "Aku Cepat Membaca". Metode belajar adalah metode yang mempunyai ciri khas dan dapat menstimulasi kemampuan membaca yaitu, Cepat, Mudah, Gembira, dan anti lupa menghapus paradigma bahwa metode belajar permulaan membaca itu mudah cepat, dan menyenangkan telah berahli pada metode yang telah teruji. (1) Adapun tujuan penelitian ini adalah: Dapat mengetahui pengaruh anak terhadap membaca permulaan dalam metode belajar "Aku Cepat Membaca". (2) Untuk mengetahui cara metode belajar dalam mengembangkan kemampuan membaca permulaan pada kelompok B.

\section{METODE PENELITIAN}

Jenis penelitian ini digunakan dalam penelitian ini adalah metode penelitian kuantitatif. Penelitian ini berjudul "Metode Belajar "Aku Cepat Membaca" Terhadap Kemampuan Membaca Permulaan Pada Kelompok B2 TK Aisyiyah 46 Surabaya", dilakukan untuk membuktikan bahwa dengan penggunaan metode ACM dapat mengembangkan kemampuan membaca permulaan anak.

penelitian ini adalah Preexperimental dengan desain One Group Pre-Test - Post Test. Merurut (Subana dan Sudrajat, 2005:98). Cara menerapkan desain ini adalah dengan melakukan satu kali pengukuran di depan pret-test sebelum adanya perlakuan treatment dan setelah itu dilakukan pengukuran akhir post-test. Teknik 
pengumpulan data yang akan digunakan dalam penelitian adalah:

\section{Observasi}

Observasi merupakan proses pengamatan dan pencatatan secara sistematis mengenai sesuatu yang telah diteliti. Burke Hedges menyatakan bahwa bacaan yang penuh daya adalah bara api seperti halnya pikiran dalam suatu kesadaran kolektif sebuah peradaban, meski hanya sedikit orang yang menyisihkan waktu untuk membaca.

Tabel 3.2

Lembar Observasi Kemampuan Membaca Permulaan Anak Kelompok B

\begin{tabular}{|c|c|c|c|c|c|c|c|}
\hline \multirow[t]{2}{*}{ Variabel } & \multirow{2}{*}{$\begin{array}{l}\text { Kompetensi } \\
\text { Dasar (KD) }\end{array}$} & \multirow[t]{2}{*}{ Indikator } & \multirow{2}{*}{$\begin{array}{l}\text { Apek yang ingin } \\
\text { dicapai }\end{array}$} & \multicolumn{4}{|c|}{ Penilaian } \\
\hline & & & & 1 & 2 & 3 & 4 \\
\hline \multirow[t]{3}{*}{$\begin{array}{l}\text { Kemampuan } \\
\text { Membaca } \\
\text { Permulaan }\end{array}$} & $\begin{array}{l}3.10 \text { Memahami } \\
\text { bahasa reseptif } \\
\text { (menyimak dan } \\
\text { membaca) }\end{array}$ & $\begin{array}{l}\text { 1.Memahami } \\
\text { masing-masing } \\
\text { bunyi pada kata } \\
\text { kunci } 1,2,3 \text { dan } \\
4 \\
\text { 2.Dapat } \\
\text { memahami } \\
\text { sintesa } 1,2,3 \text { dan } \\
4\end{array}$ & $\begin{array}{l}\text { 1.Anak mampu } \\
\text { mengenal, } \\
\text { melihat, } \\
\text { menirukan, dan } \\
\text { menghafal } \\
\text { bunyi kata } \\
\text { lembaga a da ra } \\
\text { ja, ma ha ka ya, } \\
\text { ka ta wa na,dan } \\
\text { sa ma la ba } \\
\text { 2. Mensintesa } \\
\text { secara acak } \\
\text { suku kata yang } \\
\text { terdapat pada a } \\
\text { da ra ja, ma ha } \\
\text { ka ya, ka ta wa } \\
\text { na, dan sa ma la } \\
\text { ba }\end{array}$ & & & & \\
\hline & & $\begin{array}{l}\text { 1.Dapat } \\
\text { memahami } \\
\text { masing-masing } \\
\text { perubahan bunyi } \\
\text { 2.Dapat } \\
\text { membedakan } \\
\text { perubahan bunyi } \\
\text { a,i,u,e,o }\end{array}$ & 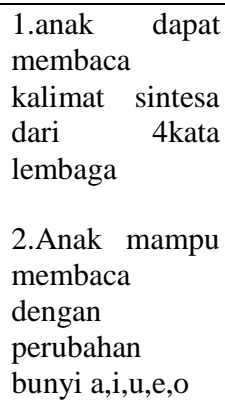 & & & & \\
\hline & & $\begin{array}{l}\text { 1.Dapat } \\
\text { memahami } \\
\text { masing-masing } \\
\text { bunyi padakata } \\
\text { kunci } 5 \text { dan } 6 \\
\text { 2.Memahami } \\
\text { dan dapat }\end{array}$ & $\begin{array}{l}\text { 1. Anak mampu } \\
\text { melihat, } \\
\text { menirukan dan } \\
\text { menghafal } \\
\text { bunyi kata } \\
\text { lembaga pa pa } \\
\text { ba ca dan a da }\end{array}$ & & & & \\
\hline
\end{tabular}




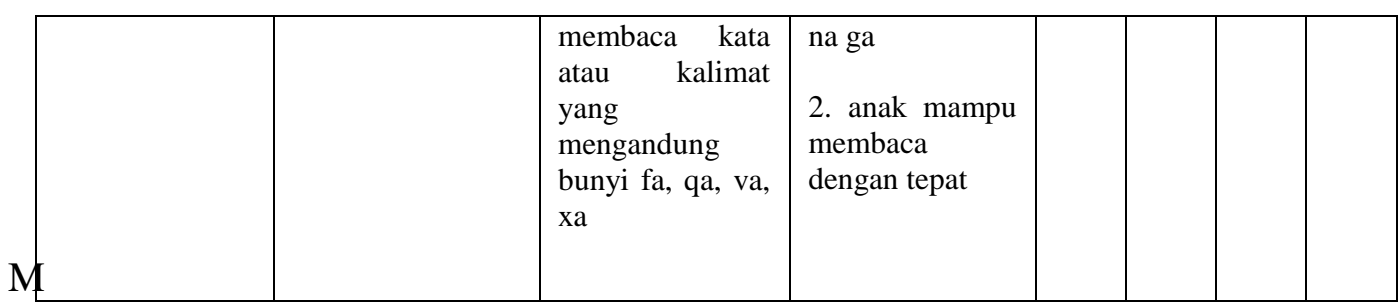

aka sesuai dengan pengukuran rating scale, Cara pemberian skor dengan kriteria penilaian dengan mengguanakan penilaian bintang yang untuk mengembangkan dalam kegiatan pembelajaran anak.

\section{HASIL PENELITIAN}

Data yang digunakan dalam penelitian mengenai kemampuan membaca permulaan anak usia dini diambil dari hasil observasi yang terdiri dari 5 indikator. Observasi ini dilakukan ketika pretest dan posttest. Pretest dilakukan sebelum pemberian perlakuan (treatment) pada kelompok B2. Sedangkan posttest dilakukan setelah diberikannya (treatment).

1. Tahap Pengukuran Awal (pre test)

Tahap pengukuran awal (pre test) adalah tahap dimana peneliti melakukan pengukuran awal terhadap kemampuan membaca permulaan anak pada kelompok B2 di TK Aisyiyah 46 Surabaya sebelum diberikan treatmen.

Berikut data penilaian anak kelompok B2 saat pre test di TKAisyiyah 46 Surabaya dengan indikator memahami tentang membaca cepat yang siap digunakan dengan kegiatan membaca permulaan.

Tabel 4.1

Data Hasil Pre test Kelompok B2

\begin{tabular}{|c|c|c|c|c|c|c|c|}
\hline \multirow[t]{2}{*}{ No } & \multirow[t]{2}{*}{ Nama } & \multicolumn{5}{|c|}{ Aspek yang dinilai } & \multirow[t]{2}{*}{ Skor } \\
\hline & & $\begin{array}{l}\text { Anak mampu } \\
\text { mengenal } 4 \\
\text { kata lembaga } \\
\text { (a da ra ja, } \\
\text { ma ha ka ya, } \\
\text { ka ta wa na } \\
\text { dan sa ma la } \\
\text { ba) }\end{array}$ & $\begin{array}{l}\text { Anak dapat } \\
\text { memahami } \\
\text { sintesa secara } \\
\text { acak }\end{array}$ & $\begin{array}{l}\text { Anak mampu } \\
\text { membaca } \\
\text { dengan } \\
\text { perubahan } \\
\text { bunyi } \\
\text { a,i,u,e,o dari } \\
4 \text { kata kuci }\end{array}$ & $\begin{array}{l}\text { Anak } \\
\text { mampu } \\
\text { membaca } \\
\text { dan } \\
\text { menghafal } \\
\text { kata } \\
\text { lembaga (pa } \\
\text { pa ba ca dan } \\
\text { a da na ga) }\end{array}$ & $\begin{array}{l}\text { Anak } \\
\text { mampu } \\
\text { membaca } \\
\text { dengan } \\
\text { benar }\end{array}$ & \\
\hline 1 & Cha-cha & 2 & 3 & 2 & 2 & 2 & 11 \\
\hline 2 & Amira & 2 & 2 & 2 & 3 & 2 & 11 \\
\hline 3 & A.syifa & 3 & 2 & 2 & 1 & 1 & 9 \\
\hline 4 & Aulia & 2 & 1 & 1 & 2 & 2 & 8 \\
\hline 5 & Ibnu & 1 & 2 & 2 & 3 & 2 & 10 \\
\hline
\end{tabular}




\begin{tabular}{|c|c|c|c|c|c|c|c|}
\hline 6 & Rama & 2 & 2 & 2 & 3 & 2 & 11 \\
\hline 7 & Reva & 2 & 1 & 2 & 2 & 1 & 8 \\
\hline 8 & Galang & 1 & 2 & 2 & 1 & 2 & 8 \\
\hline 9 & Baim & 2 & 1 & 2 & 3 & 2 & 10 \\
\hline 10 & Fathan & 2 & 2 & 2 & 3 & 2 & 11 \\
\hline 11 & Yasmin & 2 & 1 & 2 & 1 & 1 & 7 \\
\hline 12 & Octa & 2 & 2 & 2 & 2 & 3 & 11 \\
\hline 13 & Aiffal & 2 & 2 & 2 & 2 & 2 & 10 \\
\hline 14 & Nindi & 1 & 1 & 2 & 2 & 2 & 8 \\
\hline 15 & Azzam & 2 & 1 & 2 & 1 & 1 & 7 \\
\hline 16 & Diba & 1 & 1 & 1 & 2 & 2 & 7 \\
\hline 17 & Salwa & 2 & 1 & 2 & 2 & 2 & 9 \\
\hline 18 & Zahira & 2 & 2 & 2 & 2 & 2 & 10 \\
\hline 19 & Fian & 1 & 1 & 2 & 1 & 1 & 6 \\
\hline 20 & Salman & 2 & 1 & 2 & 2 & 1 & 8 \\
\hline 21 & Vivi & 2 & 3 & 2 & 3 & 3 & 13 \\
\hline 22 & Renata & 1 & 2 & 1 & 1 & 2 & 7 \\
\hline 23 & Fandi & 2 & 2 & 3 & 2 & 1 & 10 \\
\hline \multicolumn{7}{|c|}{ Jumlah } & 192 \\
\hline \multicolumn{7}{|c|}{ Rata-rata } & 8,34 \\
\hline
\end{tabular}

Berdasarkan tabel diatas dapat diketahui bahwa nilai total kemampuan membaca permulaan pada kelompok B2 di TK Aisyiyah 46 Surabaya adalah 192 dengan rata-rata 8,34 .

2. Hasil Kegiatan Perlakuan (Treatment)

Pemberian perlakuan (treatment) dilakukan pada bulan Treatmen I Proses pembelajaran berjalan seperti hari-hari biasa karena pemberian perlakuan berupa penerapan metode belajar dilakukan pada kegiatan inti kedua setelah istirahat. Peserta didik sangat
Desember-Januari di TK Aisyiyah 46 Surabaya. Perlakuan berupa penerapan metode belajar "Aku Cepat Membaca" di lakukan pada kelompok B2. Yang memiliki treatment I,II,II,IV dengan perkembangan yang berbeda-beda.

antusias terlibat dalam pembelajaran kali ini, menjadi kesan pertama yang peneliti dapatkan hampir seluruh perserta didik berdiri dan mendekat ke arah guru dengan mengajukan banyak pertama dan saling berdebat 
dalam membaca permulaan yang termasuk metode bagi mereka. Guru mulai menjelaskan cara metode belajar pada peserta didik setelah kemudian kelas kembali dan tenang. Awalnya guru menjelaskan tentang cara membaca suku kata dengan metode belajar kemudian guru mengajarkan cara membaca suku kata tersebut dan memberikan contoh berupa kegiatan membaca yang sesuai dengan suku kata yang didapat oleh guru dan metode belajar. Setelah semua penjelasan sesuai di berikan peserta didik memberikan respon mereka mereka mengerti maka tibalah giliran beberapa peserta didik maju dan membaca suku kata pada kata lembaga.

Mengenal kata lembaga dari peserta didik yang mendapatkan giliran pertama adalah takut cara membacanya salah kedalam metode. Setelah tersebut maju dan membaca dalam 4 kata lembaga guru dapat melanjutkan untuk anak mampu memahami sintesa secara acak .

Respon yang diberikan adalah mengenal, melihat, menyimak, serta menirukan yang telah dibacanya. Terlihat bingung akhirnya guru memberikan stimulus berupa ingatan yang berhubungan dengan 4 kata lembaga tersebut dan merangkai suku kata, maka peserta didik menjadi sebuah pengenalan membaca. Kemudian peserta didik menjadi di depan di minta untuk membaca kembali diri suku kata / kata lembaga. Guru kembali mengintruksikan kepada seluruh peserta didik bahwa cara belajar sambil bermain ini adalah setalah mendapatkan kata lembaga secara mudah, dan menyenangkan maka peserta didik harus membacakan dalam perubahan bunyi a, i, u, e, o yang terkait dengan suku kata tersebut.

Peserta didik yang mendapatkan geliran selanjutnya memberikan berbagai macam respon secara mudah, cepat, gembira, anti lupa dan tanpa hafalan huruf dengan menggunakan metode belajar " aku cepat membaca dengan kata sederhana. Treatmen II Pada pertemuan kedua waktu perlakuan masih sama seperti pertemuan pertama yaitu pada kegiata inti dua setelah istirahat pada pertemuan ini guru mengawali kegiatan dengan mengenalkan 4 kata lembaga seperti a da ra ja, ma ha ka ya, ka ta wa na, sa ma la ba. Pengenalan kata lembaga dasar ini bertujuan untuk menstimulasi peserta didik yang akan maju dan membaca suku kata menggunakan metode belajar "aku cepat membaca" agar dapat membaca dengan cepat dan dapat menyusuaikan cara membaca dengan kalimat yang disesuaikan dengan kalimat yang disampaikan.

Awalnya memang butuh bantuan dalam menyesuaikan membaca kata lembaga dengan kalimat yang disampaikan misalkan saat kesal karena membaca itu sulit namun dalam pengenalan membaca "aku cepat membaca" peserta didik yang membaca tersebut justru gembira, senang dan tersenyum. 
Setelah membaca kalimat selasai disampaikan anak mengingat dan membenarkan cara membaca yang di tujukan oleh peserta didik yang lain tampak mengerti dan membaca sesuai kalimat yang disesuaikan. Treatmen III Pertemuan ketiga dilaksanakan pada kegiatan inti pertama karena pada pertemuan ini guru yang akan membaca menggunakan metode belajar " aku cepat membaca" dan peserta didik sebagai penyimak yang mendengar dan menirukan cara membaca yang benar dari guru maupun dari peserta didik yang lain. Guru membaca dengan kartu kata yang di dapatkan dari metode belajar aku cepat membaca adalah pa pa ba ca peserta didik sangat memperhatikan cerita yang disampaikan oleh guru karena sebelum membaca terlebih dahulu memberikan intruksi bahwa nanti setelah membaca dengan kartu kata yang disampaikan oleh guru selesai maka peserta didik boleh menirukan, guru pun akan memberikan cara membaca yang akan ditirukan oleh peserta didik yang sudah di tunjuk. Dalam proses menirukan beberapa peserta didik membetulkan bantuan guru maupun peserta didik yang lain dalam menirukan cara membaca suku kata dalam menirukan, berapa peserta didik sesuai dengan cara membaca yang disesuaikan guru dan sebagai kurang sesuai. Namun secara keseluruhan proses meniru dan mendengarkan berjalan cukup lancar. Treatmen IV Pemberian perlakuan keempat tetap dilaksanakan pada saat dilakukan kegiatan inti pertama mengenal kata lembaga. Pada tahap ini peserta didik akan membaca ulang yang disampaikan oleh temannya. Langkah pertama adalah peserta didik membaca kalimat setelah itu guru mengajukan bebrapa peserta didik untuk membaca kembali yang didapat / didengar. Hasil pada tahap ini dapat disimpulkan bahwa lebih banyak peserta didik yang membutuhkan bantuan guru dalam membaca kembali dengan benar sesuai alur yang dibaca yang telah disampaikan karena, kemampuan membaca kalimat sudah baik dan sesuai dengan alur yang dibaca kemudian niali dari kelengkapan membaca yang di bacakan kembali sudah berkembang.

\section{Tahap Pengukuran Akhir (Post Test) \\ Data hasil penelitian pada} observasi akhir dimaksudkan untuk mengetahui kemampuan akhir anak dalam kemampuan membaca permulaan setelah diberi perlakun dengan alat penilaian berupa lembar observasi. Kegiatan post test dilakukan 1 kali sama dengan kegiatan pre test. Berikut adalah data hasil observasi akhir. 
Tabel 4.2

Data Hasil Post test Kelompok B2

\begin{tabular}{|c|c|c|c|c|c|c|c|}
\hline No & Nama & & Asp & k yang dinila & & & Skor \\
\hline & & $\begin{array}{l}\text { Anak mampu } \\
\text { mengenal } 4 \\
\text { kata lembaga } \\
\text { (a da ra ja, } \\
\text { ma ha ka ya, } \\
\text { ka ta wa na, } \\
\text { sa ma la ba) }\end{array}$ & $\begin{array}{l}\text { Anak dapat } \\
\text { memahami } \\
\text { sintesa secara } \\
\text { acak }\end{array}$ & $\begin{array}{l}\text { Membaca } \\
\text { dengan } \\
\text { perubahan } \\
\text { bunyi } \\
\text { a,i,u,e,o } \\
\text { dari } 4 \text { kata } \\
\text { lembaga }\end{array}$ & $\begin{array}{l}\text { Mampu } \\
\text { membaca } \\
\text { dan } \\
\text { menghafal } \\
\text { kata lembaga } \\
\text { (pa pa ba ca, } \\
\text { dan a da na } \\
\text { ga) }\end{array}$ & $\begin{array}{l}\text { Anak } \\
\text { mampu } \\
\text { membaca } \\
\text { dengan } \\
\text { benar }\end{array}$ & \\
\hline 1 & Cha-cha & 3 & 3 & 4 & 4 & 4 & 18 \\
\hline 2 & Amira & 4 & 3 & 4 & 4 & 4 & 19 \\
\hline 3 & A.syifa & 3 & 3 & 4 & 3 & 3 & 16 \\
\hline 4 & Aulia & 4 & 4 & 4 & 3 & 4 & 19 \\
\hline 5 & Ibnu & 3 & 4 & 4 & 4 & 3 & 18 \\
\hline 6 & Rama & 4 & 4 & 4 & 4 & 4 & 20 \\
\hline 7 & Reva & 4 & 4 & 4 & 4 & 4 & 20 \\
\hline 8 & Galang & 3 & 3 & 4 & 4 & 4 & 18 \\
\hline 9 & Baim & 4 & 4 & 4 & 4 & 4 & 20 \\
\hline 10 & Farhan & 4 & 4 & 4 & 4 & 4 & 20 \\
\hline 11 & Yasmin & 3 & 3 & 3 & 3 & 4 & 16 \\
\hline 12 & Okta & 4 & 3 & 3 & 4 & 4 & 18 \\
\hline 13 & Aiffal & 3 & 4 & 4 & 4 & 4 & 19 \\
\hline 14 & Nindi & 4 & 4 & 3 & 4 & 4 & 19 \\
\hline 15 & Azzam & 4 & 4 & 4 & 4 & 4 & 20 \\
\hline 16 & Diba & 3 & 3 & 4 & 4 & 4 & 18 \\
\hline 17 & Salwa & 4 & 4 & 3 & 3 & 3 & 17 \\
\hline 18 & Zahira & 4 & 4 & 4 & 3 & 3 & 18 \\
\hline 19 & Fian & 3 & 3 & 3 & 4 & 4 & 17 \\
\hline 20 & Salman & 4 & 4 & 4 & 4 & 4 & 20 \\
\hline 21 & Vivi & 4 & 4 & 4 & 4 & 4 & 20 \\
\hline 22 & Renata & 3 & 4 & 4 & 3 & 4 & 18 \\
\hline 23 & Fandi & 3 & 4 & 4 & 4 & 3 & 18 \\
\hline \multicolumn{7}{|c|}{ Jumlah } & 426 \\
\hline \multicolumn{7}{|c|}{ Rata-rata } & 18,5 \\
\hline
\end{tabular}




\section{Keterangan penilaian:}

1. Anak belum berkembang sesuai harapan

2. Anak mulai berkembang sesuai harapan

3. Anak berkembang sesuai harapan

4. Anak berkembang sangat baik melebihi indikator pencapaian yang diharapkan.

Berdasarkan tabel diatas dapat diketahui bahwa nilai total kemampuan membaca permulaan pada anak kelompok B2 di TK Aisyiyah 46 Surabaya adalah 426 dengan rata-rata 18,5 . Karena ada 5 aspek yang diamati maka rata-rata kemampuan membaca permulaan pada kelompok B2 yaitu 3,7 (dibulatkan menjadi 4). Karena nilainya 4 maka sesuai dengan skala pengukuran rating scale, maka kemampuan membaca permulaan anak rata-rat sebelum perlakuan (post test) adalah berkembang sangat baik.

Berikut penyajian data dalam tabel Wilcoxon Match Pairs Test

Tabel 4.5

Data Hasil Analisis Teknik Statistik Wilcoxon Matched Pars Test

\begin{tabular}{|c|c|c|c|c|c|c|c|}
\hline \multirow[t]{2}{*}{ No } & \multirow[t]{2}{*}{ Nama } & \multirow[t]{2}{*}{ (XA1) } & \multirow[t]{2}{*}{ (XB1) } & \multirow{2}{*}{$\begin{array}{l}\text { Beda } \\
\text { (XB1- } \\
\text { XA1) }\end{array}$} & \multicolumn{3}{|c|}{ Tanda Jenjang } \\
\hline & & & & & Jenjang & $\mathrm{T}+$ & $\mathrm{T}-$ \\
\hline 1 & Cha-cha & 11 & 18 & 7 & 2,5 & $+2,5$ & 0 \\
\hline 2 & Amira & 11 & 19 & 8 & 7 & +7 & 0 \\
\hline 3 & $\begin{array}{l}\text { Andi } \\
\text { syifa }\end{array}$ & 9 & 16 & 7 & 2,5 & $+2,5$ & 0 \\
\hline 4 & Aulia & 8 & 19 & 11 & 18 & +18 & 0 \\
\hline 5 & Ibnu & 10 & 18 & 8 & 7 & +7 & 0 \\
\hline 6 & Rama & 11 & 20 & 9 & 11,5 & $+11,5$ & 0 \\
\hline 7 & Reva & 8 & 20 & 12 & 21,5 & $+21,5$ & 0 \\
\hline 8 & Galang & 8 & 18 & 10 & 14,5 & $+14,4$ & 0 \\
\hline 9 & Baim & 10 & 20 & 10 & 14,5 & $+14,5$ & 0 \\
\hline 10 & Fathan & 11 & 20 & 9 & 11,5 & $+11,5$ & 0 \\
\hline 11 & Yasmin & 7 & 16 & 9 & 11,5 & $+11,5$ & 0 \\
\hline 12 & Okta & 11 & 18 & 7 & 2,5 & $+2,5$ & 0 \\
\hline 13 & Aiffal & 10 & 19 & 9 & 11,5 & $+11,5$ & 0 \\
\hline 14 & Nindi & 8 & 19 & 11 & 18 & +18 & 0 \\
\hline 15 & Azzam & 7 & 20 & 13 & 23 & +23 & 0 \\
\hline 16 & Diba & 7 & 18 & 11 & 18 & +18 & 0 \\
\hline 17 & Salwa & 9 & 17 & 8 & 7 & +7 & 0 \\
\hline 18 & Zahira & 10 & 18 & 8 & 7 & +7 & 0 \\
\hline 19 & Fian & 6 & 17 & 11 & 18 & +18 & 0 \\
\hline 20 & Salman & 8 & 20 & 12 & 21,5 & $+21,5$ & 0 \\
\hline 21 & Vivi & 13 & 20 & 7 & 2,5 & $+2,5$ & 0 \\
\hline 22 & Renata & 7 & 18 & 11 & 18 & +18 & 0 \\
\hline 23 & Fandi & 10 & 18 & 8 & 7 & +7 & 0 \\
\hline \multicolumn{6}{|c|}{ Jumlah } & $\begin{array}{l}\mathrm{T}+= \\
264,5\end{array}$ & $\begin{array}{l}\text { T- } \\
=0\end{array}$ \\
\hline
\end{tabular}


Dari table 4.5 diatas diperoleh jumlah jenjang bertanda (+) adalah 264,5 dan jumlah jenjang (-) adalah 0 . Jadi nilai $\mathrm{T}$ terkecil yaitu THitung $=0$. Dari table nilai kritis $\mathrm{T}$ untuk uji jenjang bertanda Wilcoxon untuk $\mathrm{n}=$ 23, $\dot{\alpha}=0,05$ atau taraf signifikasi $\grave{\alpha}=5 \%$ maka TTabel $=73$. Oleh karena THitung $<$ TTabel, maka Ha diterima.Ini berarti bahwa metode belajar "Aku Cepat Membaca" pada anak kelompok B2 TK Aisyiyah 46 Surabaya.

Berdasarkan table hasil perhitungan dengan menggunakan uji Wilcoxon diketahui bahwa nilai THitung yang diperoleh yaitu 0 , karena jumlah tanda jenjang terkecil dinyatakan sebagai nilai THitung.

THitung diperoleh dari hasil perbandingan dari bedahasil kegiatan pre test dan kegiatan hasil post test. Kemudian hasil tersebut dihitung pada tanda jenjang dengan hasil beda dari yang terkecil sampai terbesar. Lalu diberi peringkat dimulai angka paling kecil diberi peringkat satu dan seterusnya hingga yang paling besar.Setelah memperoleh nilai dari THitung.Kemudian THitung dibandingkan dengan TTabel.TTabel merupakan nilai dari tabel kritis dalam uji jenjang Wilcoxon. Kemudian untuk memperoleh hasil signifikasi dan mendapatkan kesalahan yang kecil, maka dalam penelitian ini dipilih tabel signifikasi $5 \%$, karena dalam penelitian ini subyek penelitian sebanyak 23 anak, maka $\mathrm{N}=23$. Jadi untuk mendapatkan nilai TTabel dapat dilihat pada tabe kritis dalam uji Wilcoxon dengan melihat taraf signifikasi $5 \%$ dan $\mathrm{N}=23$. Sehingga diperoleh THitung sebesar 0 sementara nilai TTabel dalam taraf signifikasi $5 \%$ dan $\mathrm{N}=23$ sebesar 73. Sehingga Ha diterima $(0<73) . J a d i$ dapat disimpulkan metode belajar "Aku Cepat Membaca" terhadap kemampuan membaca permulaan pada anak kelompok B2 di Di TK Aisyiyah 46 Surabaya.

\section{PEMBAHASAN}

Tahapan

penelitian

membutuhkan dalam menganalisis data yaitu tahapan melalui pretest, pemberian perlakuan dan tahapan yang terakhir adalah posttest. Peniliti melakukan observasi awal yang disebut pretest yang mempunyai kemampuan membaca permulaan digunakan sebagai pengenalan serta memahamkan cara membaca cepat namun secara sederhana.

Tahapan pemberian perlakuan diberikan setelah proses pretest akan tetapi dengan mengembangkan kemampuan membaca secara cepat yang berupa penerapan metode belajar Aku Cepat Membaca yang diambil dari hasil observasi mendapatkan sejumlah 192 dengan rata-rata 8,34 yang dapat mencakup pada indikator yang dikembangkan melalui anak 
dapat memahami masing-masing bunyi kata lembaga dari 1, 2, 3, dan 4 yang mempunyai aspek penilaian yaitu anak mampu mengenal, melihat, menirukan dan mnghafal bunyi kata lembaga. Kemampuan membaca permulaan pada kelompk B dapat berkembang bertahap pertemuan demi pertemuan yang terkadang ada beberapa anak yang tidak dapat fokus karena kurangnya semangat belajar maka nilai anak belum bisa meningkat/berkembang.

Posttest sebagai proses terakhir yang dilakukan untuk mengetahui perkembangan kemampuan membaca permulaan yang ada dalam perlakuan. Kemudian hasil postest ini sangat meningkatkan dalam proses belajar anak yang mendapatkan hasil rata-rata memuaskan dengan jumlah 426 mempunyai rata-rata 18,5 dengan menggunakan indikator memahami perubahan atau membedakan bunyi dari a, i, u, e, o adalah dapat berkembang dengan sangat baik.

Berdasarkan Hasil analisis data pretest dan data hasil post test kemudian dicari nilai selisih dari kedua proses tersebut, sehingga menghasilkan nilai jenjang yang menentukan $\mathrm{H}$ hitung untuk digunakan dalam menguji hipotesis nihil (Ho). Salah satunya menggunakan uji Wilcoxon menghasilkan nilai $\mathrm{T}+$ sebanyak 246 sementara $\mathrm{T}$ - adalah hanya bernilai 0 , data $\mathrm{T}+$ memiliki arti nilai selisih dari hasil pretest dan posttest mengalami perkembangan sedangkan data $\mathrm{T}$ - berarti nilai selisih antara kedua proses pengambilan data mengalami penurunan. Dari nilai kedua $\mathrm{T}$ untuk menentukan nilai $\mathrm{T}$ hitung adalah dengan memilih nilai yang terkecil yaitu T. Yang bernilai 0 dan dibandingkan nilai terkecil dengan $\mathrm{T}$ tabel yang diambil dari statistik uji Wilcoxon bernilai 73, sehingga hasilnya menyatakan bahwa hipotesis nihil ditolak dan dapat disimpulkan bahwa terdapat pengaruh metode belajar Aku Cepat Membaca terhadap kemampuan membaca permulaan pada anak.

sehingga dapat menghasilkan nilai jenjang yang menentukan Hhitung untuk digunakan dalam menguji hipotesis nihil (Ho) terdiri dari hasil pretest dan data hasil post test kemudian dicari nilai selisih dari kedua proses tersebut, sehingga menghasilkan nilai jenjang yang menentukan $\mathrm{H}$ hitung untuk digunakan dalam menguji hipotesis nihil (Ho). Salah satunya menggunakan uji Wilcoxon menghasilkan nilai $\mathrm{T}+$ sebanyak 246 sementara $\mathrm{T}$ adalah hanya bernilai 0 , data $\mathrm{T}+$ memiliki arti nilai selisih dari hasil pretest dan posttest mengalami perkembangan sedangkan data $\mathrm{T}$ - berarti nilai selisih antara kedua proses pengambilan data mengalami 
penurunan. Dari nilai kedua $\mathrm{T}$ untuk menentukan nilai $\mathrm{T}$ hitung adalah dengan memilih nilai yang terkecil yaitu $\mathrm{T}$. Yang bernilai 0 dan dibandingkan nilai terkecil dengan $\mathrm{T}$ tabel yang diambil dari statistik uji Wilcoxon bernilai 73, sehingga hasilnya menyatakan bahwa hipotesis nihil ditolak dan dapat disimpulkan bahwa terdapat pengaruh metode belajar Aku Cepat Membaca terhadap kemampuan membaca permulaan pada anak.

Taman kanak-kanak sebagai pendidik prasekolah mempunyai peran peting dalam memberikan stimulasi atau rangsangan dalam membaca permulaan (pramembaca) untuk menumbihkan minat membaca anak Tanan Kanak kanak. Yang pembelajarannya harus disesuaikan denga kurikulum taman kanak dan kanak dan Metode pembelajaran bermain sambil bermain. Bermain sambil belajar merupakan slogan yang harus dimaknai sebagai satu kesatuan, yakni belajar yang dilakukan anak melalui bermain.. aktifitas-aktifitas anak lebih dditekankan pada ciri-ciri bermain. Porsi bermain tampak lebih menonjol daripada belajar. Mealui bermain itulah anak memperoleh bebgai kemampuan seperti, kemampuan berkomunikasi, kemampuan berbahasa, kemampuan besosialisasi.
Menurut sholehuddin (2000) dalam Musfiroh (2008:29), bermain adalah dunia dunia sekaligus sarana belajar anak. Memberikan kesempatan kepada anak untuk bermain berarti memberikan kesempatan kepada mereka untuk belajar. Memberikan kesempatan kepada anak untuk belajar dengan caracara yang dapat dikategorikan sebagai bermain berarti telah berusaha membuat pengalaman belajar itu dirasakan dan dipersepsikan secara alami oleh anak yang bersangkutan sehingga menjadi bermakna baginya.Karena itulah pengajaran membaca Taman Kanak-kanak harus dilakukan dengan metode bermai, sehingga anak merasa senang, tertarik dan berminat untuk belajar membaca. Anak tidak merasa terpaksa untuk belajar yang akhirnya akan muncul suatu kebosanan dan tidak tertarik lagi dengan kegiatan membaca.

\section{KESIMPULAN}

Berdasarkan hasil analisis bahwa metode belajar Aku Cepat Membaca memiliki pengaruh dalam kemampuan membaca permulaan anak usia dini pada kelompok B2 di TK Aisyiyah 46 Surabaya. Metode belajar ini dapat mempengaruhi perkembangan membaca, karena metode belajar Aku Cepat Membaca merupakan metode baru yang didesaib menarik 


\begin{abstract}
supaya dapat meningkatkan ketertarikan anak untuk terlibat dalam pembelajaran perkembangan kemampuan membaca.

Dalam penyajian data penelitian yang menghasilkan jawaban bahwa metode belajar Aku Cepat membaca terhadap kemampuam membaca permulaan anak usia dini pada kelompok B2 di TK Aisyiyah 46 Surabaya dapat dilihat sebagai berikut

Diketahui :

$\mathrm{T}$ hitung $=0 \mathrm{~T}$ tabel $=$ 73Kemungkinan hasil Jika $\mathrm{T}$ hitung $<\mathrm{T}$ tabel maka hipotesis awal (Ha) diterima dan hipotesis nihil (Ho) ditolak.Jika T hitung > tabel maka hipotesis awal (Ha) ditolak dan hipotesis nihil (Ho) diterima.Dari data diatas maka hipotesis awal (Ha)diterima dan hipotesis (Ho)diterima karena $\mathrm{T}$ hitung $<\mathrm{T}$ tabel (0-73)
\end{abstract}

\section{DAFTAR PUSTAKA}

Arikunto, Suharimi. (2006).

Prosedur Penelitian

SuatuPendekatan

Praktik. Jakarta: PT

Rineka Cipta

Doman, Gleen. 1998. Mengajar

Bayi Anda Membaca.

Jakarta: Gaya Favorit

Press.

Ermiyanti.2016. Peningkatan

Kemampuan membaca

Permulaan melalui

media APE Di

Kelompok B TKIT
Hajjah Jawiyah

Badrie. Universitas

Muhammadiyah.

Musfiroh, Tadkiroatun. (2005).

Bercerita Untuk Anak

Usia Dini, Jakarta:

Departemen

Pendidikan Nasional

Sugiyono. (2015). Statistik

Nonparametris Untuk

Penelitian, Bandung:

Alfabeta.

Sulthon. M dan Tsuroyah, Nur. 2013. Aku Cepat Membaca; seri anakanak. Surabaya: Industri. 
PEDAGOGI: Jurnal Anak Usia Dini dan Pendidikan Anak Usia Dini

Volume 4 Nomor 1 Februari 2018

P-ISSN: 2599-0438; E-ISSN: 2599-042X 